\title{
Dr Arnold Berliner (1862-1942), physicist and founding editor of Naturwissenschaften
}

\author{
Sven Thatje
}

Received: 26 November 2013 / Accepted: 27 November 2013 /Published online: 5 December 2013

(C) Springer-Verlag Berlin Heidelberg 2013

Only a few years ago, we knew relatively little about the founding editor of Naturwissenschaften (NAWI), Dr Arnold Berliner, who led and developed the journal over the exceptionally long period of 22 years. It seemed that most information about his acting as editor of NAWI had been lost, most likely in the chaos of WWII and thereafter. Until about a year ago, we did not even know what Berliner looked like, with the only potential image of him being a painting by Eugen Spiro (Thatje 2012). It was by pure luck that I came across Robin O'Neil's work, who at that time had been investigating into the fate of the family of famous composer Gustav Mahler during and after the Holocaust. As it emerged, Berliner had been a close and life-long friend to Mahler, and because of this circumstance, the composer's well looked after history and belongings also revealed information about the physicist and editor, Dr Arnold Berliner. This editorial honours the man behind the origins of Naturwissenschaften. It does not aim to be exhaustive and comprehensive. I simply wish to provide a brief insight into the life and personality of a man who was much more than a simple academic of his time, but who through rigour and dedication to his work, and loyalty to his friends, most likely shaped great parts of the science and society of his time. This being a very subjective point of view, I leave it to historians to unravel the true impact of this man during difficult political and societal times of the early twentieth century (O’Neil 2014).

Berliner's life Arnold Berliner was born in the Silesian town of Breslau (now Wroclaw, Poland), on 26 December 1862. He was the son of Siegfried Berliner and Marianna (Marie)

\section{S. Thatje $(\bowtie)$}

Ocean and Earth Science, National Oceanography Centre

Southampton, European Way, University of Southampton,

Southampton SO14 3ZH, UK

e-mail: svth@noc.soton.ac.uk
Berliner (nee Friedländer), and had a younger and an older sister, Fanni and Else. The Berliners were Jews and of high culture which was of strong influence on the education and development of their children. The Berliner family was closely related to the Neisser family, and Albert Neisser (18551916) in particular, a famous dermatologist of his time. The close relation to Albert may have impacted Arnold's initial choice to study medicine in Berlin. His love of science and the arts had been apparent from an early age, but medicine was not for him, and he opted to study physics and practical applications of science, which led him to study physics at the University of Breslau. In 1886, he received his doctorate based on his studies on 'The molecular refraction of organic liquids', and much later in life he received an honorary doctorate of the Technical Institute of Aachen, and the Silver Leibnitz medal in 1922, one of the highest academic recognition Germany had to offer at that time.

For many years and before initiating NAWI, Berliner worked for the founder of the AEG (Allgemeine Elektrizitätsgesellschaft $=$ General Electric), Emil Rathenau, who had purchased rights to several of Thomas Edison's patents in the 1880s. Soon thereafter, Rathenau appointed Berliner as head of the physics laboratories of AEG and in a period of rapid expansion within the company. He led the filament lamp factory, and he was also an expert on gramophones and various other technical things. He was deeply involved in the development of the incandescent lamp and $\mathrm{X}$-ray bulbs, not knowing of the destructive power of X-rays when conducting experimental work. In a completely different area, and perhaps also driven by his love of music, he was the first to introduce the disc form for records used in phonographs. He was a first generation 'technical physicist' and worked in close collaboration with the founder of AEG, Emil Rathenau. He left AEG in 1912 because of personal differences with Rathenau. 
Berliner enjoyed a wide range of interests; he studied poetry, church history, enjoyed the classics of literature and history in general. He loved the arts and music and is known to have visited Bayreuth to experience Richard Wagner's work on many occasions. The Neissers were great Wagnerians and this likely impacted Arnold's musical understanding from an early age.

Berliner was a prolific author and in 1903 published his book Lehrbuch der Experimentalphysik in elementarer Darstellung (Berliner 1903), which in its third edition published in 1924 grew to more than 1,400 pages, containing contributions from 93 collaborators across the various areas of physical sciences. This substantial body of work is somehow demonstrative of his skill to collaborate with a vast network of scientists in order to consolidate an entire research area, certainly a skill that should have favoured his success as editor of NAWI.

Berliner was proud of being Jewish, and as a German Jew, he loved his country. At the same time and in later life, however, he developed a sense of being as a second-class citizen. He suffered from poor eyesight since childhood, which must have affected his work, and wearing thick glasses seemed to be a characteristic in his appearance (Fig. 1).

Arnold Berliner died 22 March 1942 in Berlin, aged 79. He committed suicide in anticipation of being deported by the Gestapo. In 1942, he must have been one of the very few Jews left in Berlin and house arrest and restrictions to his life including food rations, that would have ultimately starved him to death, must have been horrendous; in his final days, life must have been lonely and consisting solely of memories.

The journal Berliner's career-changing idea to develop a German equivalent to the English-language journal Nature emerged after having left AEG in 1912 and in discussions and encouragement by family and Alber Neisser. Still in 1912, he proposed to Ferdinand Springer, owner of the Springer Publishing Company, the founding of the journal Die Naturwissenschaften, which he continued to lead and develop over the following 22 years.

In a letter from 6 August 1912, Berliner outlined his vision for NAWI to Ferdinand Springer as a multidisciplinary science journal, and pushed for an early launch of the journal only a couple of months later. In his first editorial published in 1913, he stated that NAWI should 'inform all those working in scientific fields, either researchers or teachers, about what interested them outside their own fields' (translated from German; Naturwissenschaften 1(1):1; published 3 January, 1913; Autrum 1988).

Berliner's vision to fill a gap in the communication of science, in particular the need for synthesising knowledge from all the branches of science, and to translate this knowledge to lay audience, was well ahead of most journals of the time. During the Weimar Republic, NAWI gained acceptance

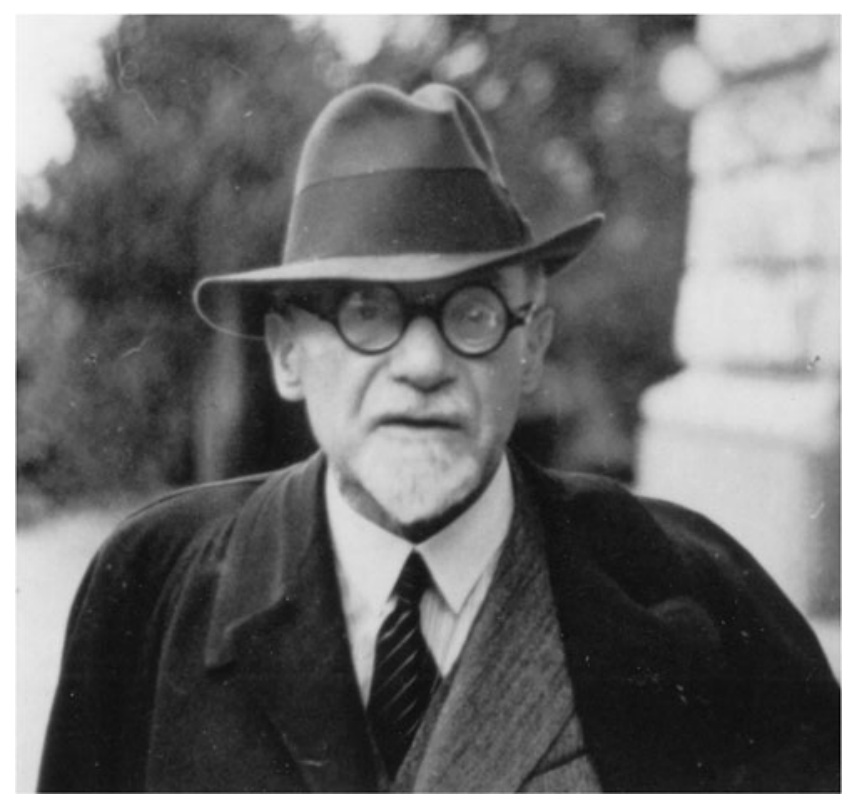

Fig. 1 Dr Arnold Berliner in front of the 'Eidgenössische Technische Hochschule' in Zurich, Switzerland (date unknown). Photograph by kind permission, thanks to Dr. Vincent C. Frank, Basel/Switzerland, from his collection Dr. Paul Rosbaud

across wide parts of educated German-speaking society, and alongside the rise of the Springer publishing company to dominate science publishing in Weimar-era Germany, and emerged as a voice for science that did not only address scientific peers (Stöltzner 2002). A citation often used in this context is that of Albert Einstein who wrote on the occasion of the 70th birthday of Berliner, 'His journal cannot be thought away from the life of our time' (Einstein 1932).

NAWI suffered from the NAZI regimes dismissal policy, which banned many authors, particularly Jewish, from publishing. By 1935, the journal suffered from shortage of contributions and a decline in overall quality of articles. On 13th August 1935, Arnold Berliner was dismissed from the journal as part of the non-Aryan policies implemented by the NAZI government. Springer had delayed the dismissal of authors and editors of Jewish origin since the first campaigns against the publisher in May 1933. Berliner had expressed his wish to lead the journal for a quarter of a century, until the end of 1937, a wish which could not be fulfilled. Berliner had prominent advocacy, such as Max Planck, to keep him in position as editor of NAWI, which, however, only had delaying effect on his dismissal. Shortly after leaving Springer employment, on 19 September 1935, he sailed to the USA accompanied by his friend Max von Laue. He was urged by friends to live a safe life in the USA, but returned to Germany, visited the USA again in 1937, but briefly, and again returned to his home country Germany.

Friendship Arnold Berliner was certainly at the heart of academic life and society of his time, and from the letters and 
reports that survived this period, it is obvious that friendships mattered a lot to him. He was friends with German physicist and mathematician Max Born, the Prussian immunologist Paul Ehrlich and he was also highly appreciated by Albert Einstein, to mention but a few.

Perhaps the most astonishing friendship is that of Arnold Berliner and Gustav Mahler, the famous composer; Berliner apparently met Mahler for the first time at the Hotel Royal in Hamburg during the 1891-1892 season. Mahler was preparing for his first series of concerts in England and Berliner started to teach him English, and especially the terminologies needed in the theatre. This friendship lasted until the death of Gustav Mahler, but, over time, personal contacts were increasingly sporadic because of Mahler's enormous workload. However, when Gustav Mahler died in 18 May 1911, Berliner was there at last.

Their time in Hamburg was probably the longest both saw of each other. In the following years, Berliner advised Mahler in matters of money, contracts, and lent him money when Mahler asked him for help. Both characters were as contrasting as they could have possibly been, and the frequent letters exchanged indicate a clear distinction of emotional affection and artistic matters. Gustav Mahler was chiefly interested in science and science discussion, and Berliner supplied him with books and literature of interest. On the other hand, Mahler, in letters to his sister Justine, regarded Berliner as highly pedantic and difficult to get on with.

Indeed, Berliner was pedantic in his acting as editor and likely had been the same as leader of a lab. It was his dedication to science, and loyalty to his work and friends that earned him the highest respect by those around him. Again, it was Albert Einstein who, in a few lines, probably summarised the nature of Berliner's character at best. In his accolade, in honour of his friend's 70th birthday, he stated:

Berliner's fight for clarity and comprehensiveness of outlook has done a great deal to bring the problems, methods, and results of science home to many people's minds. The scientific life of our time is simply inconceivable without his paper... It is just as important to make knowledge live and to keep it alive as to solve specific problems. We are all conscious of what we owe to Arnold Berliner.

Do not be angry with me for this indiscretion, my dear Berliner. A serious-minded man enjoys a good laugh now and then.

Acknowledgments My sincere thanks go to Dr Robin O'Neil for bringing back to life details of the life of Arnold Berliner; information, which otherwise and without doubt, would have been lost in the not too distant future. Most of the facts presented in this Editorial are based on his research to which I refer (O’Neil 2014). Springer Science + Business Media established the Arnold Berliner Award and in recognition of Arnold Berliner as the founding editor of the journal, which is greatly acknowledged. The award is given annually for the best research article published in NAWI during the previous calendar year (Thatje 2012), and was awarded for the first time in 2013, and as part of the centenary celebrations of Naturwissenschaften (Thatje 2013). I thank James P. Morris for comments on the draft manuscript.

\section{References}

Autrum H (1988) Arnold Berliner und die "Naturwissenschaften". Naturwissenschaften 75:1-4

Berliner A (1903) Lehrbuch der Experimentalphysik in elementarer Darstellung. (2nd edition in 1924) Gustav Fischer, 867pp

Einstein A (1932) Zu Dr. Berliners siebzigstem Geburtstag. Naturwissenschaften 20:913

O'Neil R (2014) The Mahler Family in the Rise and Fall of the Third Reich. Diadem Books (in press)

Stöltzner M (2002) Mit Mimose und Stachelschwein (Arnold Berliner und Die Naturwissenschaften). Süddeutsche Zeitung, 22 March, p. 13

Thatje S (2012) Introducing the Arnold Berliner award. Naturwissenschaften 99(9):675-676

Thatje S (2013) The Arnold Berliner Award 2013. Naturwissenschaften 100:485-486 